\title{
A Governance Approach to Regional Energy Transition: Meaning, Conceptualization and Practice
}

\author{
Thomas Hoppe ${ }^{1, *(1)}$ and Michiel Miedema ${ }^{2,3}$ \\ 1 Faculty of Technology, Policy and Management (TPM), Department of Multi Actor System, Organisation and \\ Governance, Delft University of Technology, Jaffalaan 5, 2628 BX Delft, The Netherlands \\ 2 Stadlander, Rooseveltlaan 150, 4624 DE Bergen op Zoom, The Netherlands; michiel.miedema@stadlander.nl \\ 3 Master City Developer, Erasmus University Rotterdam, Burgemeester Oudlaan 50, 3062 PA Rotterdam, \\ The Netherlands \\ * Correspondence: T.Hoppe@tudelft.nl; Tel.: +31-15-27-82783
}

Received: 5 November 2019; Accepted: 23 January 2020; Published: 26 January 2020

check for updates

\begin{abstract}
Energy transition requires action from different levels of government. While the national and local level have received ample scholarly attention, thus far little attention has been paid to the regional level. This is remarkable because policy makers across Europe are wondering what governance of regional transition actually is and how to shape and implement it. In the present paper, this concern is addressed. The research questions are, "What does regional governance of energy transition entail? How can it be conceptualized? And what does it mean in practice?" The questions are answered by presenting the results of a multi-disciplinary literature study, presenting a conceptual framework on governance of regional energy transition, using insights from innovation and transition studies as well as from the regional and network governance literature, and applying this to the illustrative case of the West-Brabant region in The Netherlands. West-Brabant is a relatively large region and was home to a pilot that involved the development of a regional energy strategy. Data collection involved twenty expert interviews, text documents and participative observation in workshops. Results highlight the relevance of each of the key elements of the conceptual governance framework. However, some are particularly relevant like structural characteristics of the regional actor network, actor characteristics, and regional governance arrangements used. The results reveal commonalities with regional governance in other policy domains. This paper contributes to the literature on polycentric governance of energy transition and climate change mitigation, and concludes with the presentation of a research agenda.
\end{abstract}

Keywords: governance; network; policy; sustainable transition; region; multi-level governance; polycentric governance; energy transition

\section{Introduction}

Regional energy transition (RET) [1] is a topic that is receiving increasing attention from policy makers across Europe. It can be seen as an issue that calls for polycentric governance in light of climate challenge [2]. Not only are EU Member States active in setting national government low carbon targets, releasing new climate laws, developing new climate programs, and formulating new climate policies, their national governments also encourage their decentralized counterparts to contribute to the COP21 Paris Agreement. Local administrations-currently typically large-sized municipalities with experienced staff and with sufficient capacities-formulate and run progressive programs, while taking on different roles, from initiator to regulator and facilitator, also depending on the degree of authority they have vis-à-vis national government [3-6]. In this way, national government sets the governance conditions and supportive policy instrumentation that local administrations can use, 
tailoring their programs and policies to local conditions, with the aim to meet low carbon goals (and co-benefits) and accordingly contribute to the climate mitigation goals of national government. While this model makes sense theoretically, in practice, it is suboptimal, because it leaves out an important territorial level in between the national and local level: the regional level.

This is problematic because local administrations often have renewable energy projects that have cross-municipal implications, often with great implications for the space and environment of those who are directly affected by it - for instance, the siting and planning of a wind park that will be developed (typically) at or just across the border between local jurisdictions, with local communities being affected in positive ways (e.g., business development job generation, having a green image) but also in negative ways (i.e., negative externalities pertaining to landscape view, perceived lowering of property values, unjust allocation of cost and benefits between community members, perceived health risk, etc.). More in general, large-sized wind and solar parks as well as electricity supply and heat infrastructure, have implications that go beyond single municipal jurisdictions. When plans for these renewable energy projects or heat infrastructures reach political or policy agendas locally their cross-jurisdiction implications also require inter-municipal decision making. This is important to avoid zero sum games in which one local administration will reap the benefits while the others suffer from unfair sharing of costs and benefits. This also touches upon the more general disputed issue in regions, with large-sized cities having larger capacities, investment room and interests than their smaller counterparts, i.e., the small- and medium-sized cities in the rural, periphery that surround these cities.

Given the polycentric and multi-level character of climate change mitigation and energy transition governance, as well as the struggles that actors encounter in inter-municipal decision-making arenas and the issues and interests that are at stake, interestingly, the issue of energy transition at the regional level has received surprisingly little scholarly attention. While a plethora of scholarly publications are available addressing governance of local energy transition (including the literature of cities and climate change (mitigation) literature; [7-9], and the governance of energy transition at the national level [10,11], except for techno-economic potential and modelling studies—e.g., [12,13]—there has been remarkably few attention to the governing of energy transition at the regional level. Although there is a growing number of scholarly studies available on RET [1], few actually focus on regions as the level where inter-municipal issues manifest themselves and are addressed. The majority of these studies either focus on the local level (e.g., [14]) or on the provincial level (and actions provincial governments engage in; e.g., $[15,16])$.

This paper taps into the knowledge gap of governing energy transition at the regional level to address inter-municipal issues pertaining to energy transition, and presents its meaning, relevant theoretical concepts, and its implications. The goal is to present a conceptual overview of RET governance and to present an empirical case to illustrate this. In this paper, relevant conceptual and empirical insights from different academic disciplines, such as transition studies, regional innovation studies, policy studies and governance, are presented, including insights from studies on regional governance. This leads to the elaboration and presentation of a conceptual framework on regional-i.e., inter-municipal-governance of energy transition. The research questions of this paper are, "What does regional governance of energy transition entail? How can it be conceptualized? And what does it mean in practice?"

This paper is structured as follows. In Section 2, literature addressing RET in innovation and transition studies is presented. In Section 3, literature addressing RET from a governance perspective is addressed, with special attention to network governance and regional governance studies. In Section 4, based on conceptual insights from these literatures a conceptual framework on the governance of RET is presented. Section 5 then presents research design and methodology of the present study pertaining to an illustrative case study. In Section 6, the results of the case are presented, and in Section 7, they are discussed (i.e., positioning of results in relevant academic debates). Finally, in Section 8, conclusions, limitations, and suggestions for future research are addressed. 


\section{Regional Energy Transition in the Innovation and Transition Literature}

Attention to RET and the governance thereof in the academic literature is scarce. While regional energy transition is mentioned, its locus often pertains to other levels of government-i.e., local or provincial-and not regional, pertaining to the level in between. As such, the regional level can be seen as a sub-level to the provincial level, and super-level to the local level, related to configurations of kore or less collaborating municipalities in certain delineated geographical spaces. Regions can either be delineated geographically (i.e., in terms of a city-region, or a certain part of a province), culturally or historically, but they can also be delineated in functional terms (e.g., a region in which municipalities collaborate on safety issues or a policing regions in which policing entities collaborate to create more law enforcement capacities that collectively contribute to increasing safety levels). When searching for energy transition literature on this very scale one encounters surprisingly few academic publications. The articles that are found can roughly be discerned into different disciplinary backgrounds, with regional innovation studies and transition studies on the one hand, and governance studies on the other. Key results and concepts used in studies are presented in the sections below.

\subsection{Regional Innovation Studies}

The regional innovation systems discipline (RIS) offers a comprehensive framework to analyze the innovative capacity of regions [17]. RIS studies are conducted by mapping the key elements and mechanisms of a (socio-technical) system [18]. First, relevant firms and organizations in the RIS are identified, along with as their knowledge linkages and networks. Moreover, situational (local) advantages and disadvantages are addressed to address the importance of proximity [19]. Second, the governance system that underpins the coordination and decision-making processes pertaining to innovation is analyzed. In RIS there is a focus on policy instruments and mostly 'policy mixes', i.e., mixes with "carrots, sticks and sermons" [20]. When regions miss such systemic structures and governance arrangements the likelihood is low that there will be innovative capacity, and neither is transformative change to be expected. If there is a need to establish this, it requires organizational and institutional innovation as to develop 'working configurations' that pertain to actors, networks and institutions that could act as 'proto-innovation systems' [21]. What might help in this regard is to align visions, coordinate actions, and to attract more attention. For instance by branding regions (and arguably the role of key regional cities therein; [22]). An example would be the 'Energy Valley' brand that is used in the Province of Groningen in The Netherlands, indicating the focus on energy innovation in the region [23].

In their study on regional energy systems of the German cities of Bottrop and Emden, Mattes et al. [14] stress that prevalent theories in the debate on sustainability transitions do not sufficiently address energy change processes at the local and regional level. Drawing on concepts from Regional RIS they argue that local development dynamics result from the interaction of various subsystems, like science, politics, public administration, industry, finance, intermediaries or civil society. It is certain "spheres" that shape innovation [24]. This pertains to questions like: Which are the subsectors involved in (regional) energy transition, do actors from various subsystems participate, and do regime outsiders participate? Subsystems, "spheres" and their interactions influence the ways energy transitions are shaped locally by different individual and organizational actors as well as institutions and involve an active role for intermediaries. Although RISs are shaped locally one should not forget that regional systems are embedded in national and even supra-national systems [25].

Lutz et al. [26] analyzed regional drivers for implementation of renewable energy projects in Germany. They discern five clusters of regional drivers: (i) planning and process (e.g., duration of process, program, regional planning and policy, and support by decision makers); (ii) exchange and participation (e.g., citizen and stakeholder involvement in decision-making processes); (iii) actors and networks (e.g., the key regional actor network, and actor heterogeneity); (iv) economic circumstances (e.g., available funding sources, regional economy, community energy initiatives); and (v) the region's status (e.g.,. at the administrative level, and membership status in issue networks). In their analysis, 
Lutz et al. [26] mapped barriers that were encountered by actors who wanted to implement renewable energy projects. They entailed to challenging political priorities, delay in administrative processes, changing laws and regulations, complaints by residents, (environmental) laws and regulations, changes in funding (schemes), complaints by participants in the process, unexpected costs, technical problems, and personal disagreement between participants even causing participants to leave projects. Implications of the study pertain to the importance of process management, strong engagement in formal networks, and the ability to combine funding from different sources. The latter also relates to regional governments having grant schemes available to stimulate climate community initiatives by competition, like the German Bundesland Nordrein-Westfalen implementing a competitive scheme that contributed to the City of Saerbeck becoming a 'Klimakommune' (i.e., climate community; translation by the authors; [27]). Finally, it should be noticed that local governments differ considerably in their activities toward renewable energy projects [26].

\subsection{Transition Studies}

Transition scholarship studies socio-technical system change. Historic regime transformations develop from the accumulation of niches, or protected spaces where practices differ from regimes and mainstream markets, and where innovations can develop and experiments can be conducted [28-30]. In addition to focusing on experimentation and niche development, transition scholars argue that system changes is influenced by dynamics between three levels of abstraction: (i) the niche level, where local experimentation and niche accumulation takes place; (ii) the regime level, where socio-technical regimes with locked-in technologies, incumbency, institutions and practices exist with the aim to maintain the status quo, forming a hostile environment to innovations that potentially threaten the very existence of the present system; and (iii) the landscape level, where impactful global events take place-like wars, economic crises, environmental disasters, geopolitical events, supranational decision making - that influence both regime stability and the emergence and development of niches [31,32]. While the niche level is mostly associated with the local and regional level, the regime level is associated with the nation-state level, and the landscape level with events of supranational scale. Transition scholarship has delivered a body of theoretical frameworks with the aim to analyze and learn from historical transition by using the multi-level perspective [32], or the normative-prescriptive aim to 'manage' future and ongoing socio-technical transitions. Of the latter key theoretical frameworks pertain to Strategic Niche Management (SNM) and Transition Management (TM). SNM can be seen as a framework for managing or governing sociotechnical niches in order to promote desired (sustainable) system change, whereby it focuses on both experimentation and niche development, as well as the strategic breakdown of socio-technical regimes [30]. While SNM roots mostly in transition literature and its disciplinary predecessors, TM can arguably be seen as an approach that combines insights from SNM and MLP with insights from another discipline, i.e., governance and policy studies. TM seeks to structurally change complex societal subsystems by stimulating a process of co-evolution between technology on the one hand and socio-technical elements on the other that mutually reinforce each other and are congruent in time and space, and assume multi-level dynamics between the niche, regime and landscape levels. TM assumes that transitions undergo several phases-pre-development, takeoff, breakthrough, and stabilization-and develops concepts and approaches that support instrumentation and agency in these to bring about systemic change. This takes place in a multi-actor environment with an important role for government as agent of change. Transition arenas support multi-actor development of visions, deliberative decision and policy-making, as well as coordination of actions to set up, manage and evaluate niche experiments that contribute to niche development. Decision-making takes place in multiple consecutive deliberative rounds. TM is active in multiple levels, i.e., the strategic level, the tactical level, and the operational level $[11,33]$.

Although there are plenty of studies addressing energy transition at the national and local level, remarkably little attention in transition scholarship has been awarded to the regional level. A good example of a study that does pay attention to this level was conducted by Loorbach and Rotmans [34], 
who analyzed the 'Parkstad' region in The Netherlands using a TM approach with specific attention to experimentation and the use of deliberative transition rounds. In common with the RIS approach an analytical focus on subsystems was used. In addition to an 'arena of arenas' covering multiple subsystems, sectoral arenas were set up focusing on single subsystems and themes (like 'energy' or 'mobility') having experiments of their own. The study revealed the importance of properly implementing a TM approach; for instance, having a focus on process impact instead of on mere output or outcome indicators, and setting up a development organization to coordinate actions, and platforms where actors could interact and share experiences. Moreover, a multi-actor forum was established that existed separately from the political arena in order to support niche formation processes. This included the setting of joint expectations, alignment of expectations, joint problem finding, and identifying potential transition experiments.

The study also showed that local governments were keen to start new modes of collaboration and were even willing to transfer some of their authority to the regional level (according to the so-called 'Common arrangements Act' which warrants authority at the regional, inter-municipal level). Moreover, the existing network was initially dominated by public actors, but soon expanded by allowing societal actors to join in (e.g., housing associations). Moreover, a 'Transition Document' was developed that gave the (already existing) 'Parkstad organization' a mandate to act and served as a strategic guide to inspire future actions. This helped to encourage the participating actors in their individual endeavors, and particularly to abandon fatalistic attitudes [34].

Key lessons drawn from the Parkstad case reveal that the context-specific character of regional transition processes is of key importance. However, the study also showed that regional multi-actor decision-making processes are intense, emotional, filled with tension, and need to address both formal and informal issues. As such, there is a need for sound process management and guidance by professional, experienced teams. The latter pertains to preparing the regional transition arena, i.e., selecting frontrunners (and other actors; composition matters), giving space to frontrunners, empowering them, interaction with incumbent actors, coping with unexpected events and with difficulties to specify process outcomes and effects. In addition, attention was payed to the development of shared discourses, creative ideas, the creation of a common language between regional stakeholders, and support of the latter to generate higher levels of trust amongst each other [34].

More recently, a few more studies have been conducted using transition studies theory to develop methodologies or empirically study energy and climate-related transition policy at the regional scale. Frantzeskaki et al. developed a methodology that combines transition management and high-end climate change and socio-economic change scenarios to identify pathways to encourage policy makers and stakeholders to move Europe closer to sustainability. The methodology covers a sustainably pathways approach and includes application to the regional level [35]. Roessler et al. view regional energy transition from SNM and MLP perspectives and study how multi-scalar policies influence the implementation and support of bioenergy village cooperatives as a sustainable niche. They argue that supplementing the national policy framework with regional and local policy makers is of key importance [36]. Moss et al. analyzed the implementation of Germany's energy transition focusing on organization and ownership in urban and regional contexts. They conceptualize the institutional dimension to urban and regional energy transitions in terms of agency and power, ideas and discourse, commons and ownership. The paper particularly addresses the issue of urban and regional energy governance and how it is positioned vis-à-vis novel forms of collective ownership, and how this is seen from a political perspective [37]. This said, the approach taken should not only be seen from a scholarly transition theory perspective, but also from an institutional theory perspective.

\section{Regional Energy Transition in the Governance Literature}

A region can be defined as an intermediate tier of government between the lowest, local tier and national government, with at least 150,000 inhabitants per regional unit on average [38]. Regional governance can be seen as a layer of governance in between the local and state government levels, or-in 
some countries-in between the local and provincial government levels. Aside from analyzing regions from a multi-level governance perspective (addressing interdependencies between different levels of government), one can also analytically focus on regions using a network governance perspective. Andersen and Pierre [39] and Jacobsen [40] see (regionally oriented) policy networks as 'strategic regions', or rather deliberately designed, intentional structures, instruments or tools that are voluntary constructions, and are not the result of a mandate from an external actor. Moreover, they see regions as a means for collective action to solve problems individual actors (in particular municipalities) cannot solve on their own.

\subsection{Regional Governance}

In academic discussion, there has been a lot of attention to the desirability of regional governance as a separate governance level in between the local and provincial level. In Western European countries, the issue has seen several reforms, leading to calls for establishment of administrative, 'mini provinces' and the establishment of so-called 'city-regions'. In some countries a compelling need for a formal mandate of regional governance emerged. For example, in The Netherlands in 1984 the Act on Administrative arrangements ('Wet gemeenschappelijke regeling' in Dutch; translation by the authors; abbreviaton: ' $\mathrm{Wgr}$ ') came into force providing the formal foundation of for collaboration between municipalities, provinces and water boards. In practice, it mostly focused on the strengthening of inter-municipal collaboration. Although the formal arrangement encompassed multiple forms, a form often used concerned the variant comprising of a public body with legal personality, a general board, a daily board, and a chairman. Ever since, every Dutch municipality participates in multiple 'Wgr'-arrangements (in a number of different public domains like social services). In total, this led to the creation of vast number and diversity of inter-municipal collaboration forms. In general, Wgr is used by municipalities to address issues that require inter-municipal collaboration, in particular to make operations that go along with policy implementation more efficient. In addition, so-called functional regions have come into existence, implying mandatory inter-municipal collaboration in a number of domains including policing, safety, youth care, labor and enforcement of environmental policy [41].

Although the collaboration arrangements are credited for many benefits, they are also criticized for creating opaque structures, in which it is not clear who is actually responsible for which task, creating 'administrative fuss'. In addition, inter-municipal collaboration (and the resulting networks) are criticized that they 'fill in' and 'hollow out' local governance, particularly in relation to democratic control of the executive power. A Norwegian study among 77 municipalities, however, showed that there is only moderate evidence in support of these claims [40].

Boogers et al. [41] analyzed the effectiveness and democratic quality of regional governance in The Netherlands among 393 Dutch municipalities. Results show the importance of regional collaboration. Over $75 \%$ of the municipalities surveyed state that inter-municipal collaboration is necessary to develop effective policy, attain important local policy goals, improve service provision and municipal operations. The study also showed that smaller municipalities are most in need of inter-municipal collaboration, particularly in relation to the development and proper implementation of local policies, and to lower the vulnerability of municipal organizations. In addition, nearly $75 \%$ of municipalities stated that inter-municipal collaboration results in benefits for the municipality, while ample $75 \%$ noticed regional benefits resulting from inter-municipal collaboration. Explaining for sound collaboration ties, democratic influence and effectiveness of regional governance, the most significant result was collaboration based on the use of formal arrangements, which provides a judicial foundation, sets the institutional rules, is binding, and therefore makes collaboration less open-ended. In other words, when inter-municipal collaboration is organized under a uniform legal regime this leads to lower costs and higher benefits. Another key result of the study was that regional governance is less dependent on the structure of inter-municipal collaboration than on the culture of inter-municipal 
collaboration (Ibid.). Moreover, cooperative climate and trust (as a cultural variable) contribute to perceptions of effective and efficient cooperation [42].

\subsection{Network Governance}

Public governance has changed in recent decades [43]. From centrally organized forms of governance with government steering target groups while using policy instruments in hierarchical ways, a shift has occurred to network governance in which so-called policy networks, that consist of multiple interdependent actors that are connected by some form of structural dependence on each other, whereby one unit is not subordinate to the other by a formal position, and in which some form of inter-organizational coordination takes place [44] have prominent roles in policy formulation, implementation and coordination between policy programs [45]. Networked forms of governance are said to be better capable of handling complex societal, poorly structured (and even 'wicked') problems $[46,47]$ than more traditional forms of governing that assume hierarchical relationships $[48,49]$. Klijn [50] defines network governance as, "more or less sustainable patterns of social patterns between reciprocally dependent actors, which cluster around certain policy or other social problems." Provan and Milward [51] argue that network governance applies to situations where services or products are the outcome of a partnership between different organizations.

Like other forms of governance, network governance entails an instrumental approach of its own: network management. This pertains to how actors who are part of networks jointly decide what type of organization the network should be, how coordination takes place, what the goals of the network are, and by which strategy, tactics, planning and policy they should be attained. In order to attain network goals and maintain successful functioning of the network proper network management should include stimulating win-win situations, (de-)activation of actors and resources, lowering of interaction costs, gaining commitment and compliance, political-administrative coordination, quality and openness of interaction [50]. Provan and Milward [51] hold that networks require the use of network organizations, for instance leadership organization networks (that entail a leader and network manager who coordinate actions) or the use of a network administrative organization (that entails a separate organizational entity tasked to manage and coordinate actions between the network members).

De Bruijn and Ten Heuvelhof [52] state that network strategy, role and position of network managers are of great importance to the success of network management, and that network management requires proper management of decision making processes (i.e., process management). The functioning and outcomes of network interactions between network members is influenced by the extent to which the actors within the network trust each other and undertake strategic behaviors. Process management seeks to address this maintain or improve this trust base and therefore addresses transparency, risk management, the creation of commitment and consensus and support for decision making in networks (Ibid.). Network managers are said to act quickly, organize processes in clever ways, act responsibly and consistently, and show to have vision [53].

From the body of knowledge on policy networks it can be argued that the following network elements are directly or indirectly related to network performance (at the collective level).

Overall structural characteristics of the network. This entails issues like number of actors (i.e., network size; [54], geographical scope, functional scope, presences of multiple levels of government [51,55] like the involvement of actors from multiple economic sectors; involvement of actors from both the public and private sector, polycentric decision-making centers, the level of cohesion between network actors, the presence of strategic or advocacy coalitions [56], the presence of sub-clusters of actors, structural holes or weak ties between clusters of actors [57], or the presence of actors from both urban areas and the rural periphery.

Network composition addresses the actors involved, the roles they have within the network at large, actor heterogeneity (i.e., the degree in which different types of actors are part of the network, e.g., regime insiders and regime outsiders), and the type of network (see the previously mentioned types of network organization by Milward and Provan [51]). Network composition also addresses 
other structural characteristics of networks like the trust actors experience towards each other within the network [49]. Trust also indirectly influences the degree in which actors of a networks reach commitment on goals and strategy of the network and compliance to deploy resources individually to attain collective network goals [58].

Actor characteristics: This pertains to (access to) resources like capacity, knowledge, and the way actors mobilize their resources to exercise power in decision-making processes [59], but also to goals and motivation of the actors involved in the networks, and addresses the ways and degree in which they are aligned between actors [59].

Network governance (at the collective network level) pertains to the strategy or program of the network, its strategical agenda [49], degree of actor participation in decision-making rounds, the (institutional) 'rules of the game' [60], network constitution [50], the application of process management [52], the way in which leadership and control is exercised [51], the presence of a network organization (Ibid.), the presence of a (proper, experienced) network manager (e.g., initiator, regulator, facilitator; [52]), and the use of network management (and policy) instruments.

\subsection{Governance Studies and Energy Transition at the Regional Scale}

Several studies have been conducted addressing the role of governance in RET. One obvious approach would be that of decentralized governments seeking to support sustainable innovation in regional energy markets. Since provincial governments are keen on supporting regional socio-economic development they might want to set up regional innovation programs to support research and innovation of regional energy economies that mirror unique regional characteristics, and that have the potential to foster comparative cost advantages over other competing regions. An example would be the Province of Overijssel in The Netherlands supporting bio-energy research and innovation via an innovation program utilizing the regional availability of biomass [61]. Although innovation programs may provide an impetus to RET they encounter challenges when they translate into innovative projects at the local and regional level. A study on the planning and roll out of regional, inter-municipal sustainable heating grids, for example, showed that many aspects of the planning of the infrastructure are poorly regulated and lead to high degrees of uncertainty. Finding and selecting the most favorable mode of coordination proves challenging. The study revealed that selecting the right mode of governance could arguably be seen as the main challenge to RET [62].

Fuchs and Hinderer [63] stress the importance of the situational context and the political dimension in RET. They argue that transitions are foremost locally and regionally organized, and that important technical and institutional innovations for energy transitions are developed, tested, and brought to application at the regional and local levels, in the shadow of regulatory and market frameworks that are in force. It is there that new governance structures are developed that mirror space-specific social, political, technological, and economic constellations. The authors [63] introduce an analytical approach from political sociology— "Theory of strategic action fields; Lines of conflict" [64]—for studying emergent forms of governance and paying attention to agency and political struggle. They argue that sustainable energy transitions do not follow a master plan nor are they coordinated at the national level. It is rather a variety of regional actors with different aims and interests whom are involved in these processes, culminating in the development of space-specific technological mixes and situational governance structures. These, however, harbor lines of conflict between (coalitions) of actors pursuing different interests.

More in general, this pertains struggles between the coalition(s) of newcomers and those that are embedded in incumbent structures and institutions. Nonetheless, those who pursue sustainable innovation and experimentation also depend on these-for instance, urban initiatives are strongly driven by national and regional governments implementing intergovernmental policies (like support schemes) to enable local governments in the design and implementation of low carbon policies, and empowering local communities to take low carbon action of their own [65]. As such, cities, but also regions are situated in complex public and private networks with a high degree of interdependency 
between the actors involved. In other words, one cannot expect that cities and regions (in Western European countries) start low carbon initiatives and achieve their goals individually. In contrary, in practice they are quite dependent on the willingness of other actors to support them in achieving their goals, especially from higher tiers of government [3].

From this perspective it makes sense to observe cities as loci in regions in which the dynamics and interplay between urban and rural realms are reflected [66], and not merely as agents of change who can operate and govern transitions on their own. Taking into account their dependent role, agency and need for information, city administrations engage in regional, inter-municipal climate change issue networks [67]. Participation in these networks helps them to become better informed, gain awareness, and set up collaborative strategy and actions with peers to develop collective action that has a sound support base and is potentially more effective and efficient to achieve low carbon goals and associated co-benefits. Moreover, it allows a learning environment in which cities can learn from each other and avoid doing unnecessary work [1]. Several studies show that inter-municipal networking pays off [68]. It is also related to higher policy output $[69,70]$. This is important for regions with an active history in inter-municipal network collaboration, which differs from regions with large-sized cities in which the latter mostly collaborate with peers, national government and international partners, but hardly collaborate with their regional smaller counterparts in the rural hinterland.

Another issue pertains to the fact that regional governance of sustainable transition takes place in the shadow of major political and governance events at the national level. More in general, national government initiates the agenda of sustainable transition and related policy issues, and decentralized governments follow. A study on regional governance of near zero energy buildings in Dutch provinces revealed that actors experience difficulty achieving energy-neutral housing policy goals, at the stage of framing, assessment and comprehension of the agenda, and that, provincial governance primarily involved incumbent social networks resulting in limited development of regional and local configurations in terms of new roles, new responsibilities or new relationships [15].

In addition to addressing network governance and inter-municipal collaboration, it is also important to address the legitimacy of regional governance arrangements, although legitimacy and normative concepts on the role of the regulatory state are hardly addressed in the scholarly literature devoted to low carbon transitions. Nonetheless, legitimacy should not be regarded as a given standard. Although it may be designed into structures and ambitions, legitimacy will only be achieved by proper practice in governing [71].

Reaching legitimate modes of regional governance also pertains to the way in which civil society is embedded in regional governance structures-for instance, community energy collectives have a high potential vis-á-vis initiating, implementing and facilitating low carbon energy projects at the local level while enabling regional collaboration. This assumes that conditions apply pertaining to the presence of intermediary structures and supportive governance arrangements. While these intermediary structures-that are typically supported by provincial governments-are generally considered supportive to empower community energy collectives, they also create hierarchical dependencies that discourage civic action [72] and therefore run the risk of influencing situational regional governance in negative ways. Moreover, decentralized public authorities do not always have positive attitudes towards civic low carbon action (i.e., community energy collectives). A study by Warbroek and Hoppe [16] showed that the former are reluctant to share or transfer authority to the latter, which is portrayed by problems emerging in terms of bureaucratic response and 'wounded lion' civil servants protecting their interests, spheres of influence, and traditional ways of working, which leads to counterworking and even opposing of community energy action (e.g., in legal permit granting procedures) even in cases in which local politicians have declared to be general supportive to proactive civic action [16]. 


\section{Towards a Conceptual Framework to Address Governance of Regional Energy Transition}

Taking into account the conceptual and empirical insights from Sections 2 and 3 a conceptual framework is elaborated that addresses multiple facets of governance of regional energy transition (See Table 1). Although Table 1, at first glance, seems to particularly resemble the use of concepts from network governance it also covers insights and concepts pertaining to studies in innovation and transition studies, as well as regional governance.

Table 1. Characteristics of a networked approach to governance of regional energy transition (RET).

\begin{tabular}{|c|c|}
\hline Characteristic & Indicators \\
\hline \multirow{6}{*}{ Structural characteristics of the regional network } & Size \\
\hline & Degree of complexity \\
\hline & Polycentric decision-making arenas \\
\hline & Cohesion \\
\hline & Presence of clusters, sub-networks and coalitions \\
\hline & (Weak) ties to other networks \\
\hline \multirow{7}{*}{ Regional network composition } & Actor membership and heterogeneity \\
\hline & Scope (multi-level, multi-sector) \\
\hline & Involvement of regime outsiders \\
\hline & Interaction with incumbents \\
\hline & Interaction of subsystems \\
\hline & History of network actor interaction \\
\hline & Culture of interaction \\
\hline \multirow{5}{*}{ Actor characteristics } & Motivation and goals \\
\hline & Cognition \\
\hline & $\begin{array}{l}\text { Access to and ownership of resources (e.g., competences, } \\
\text { knowledge, capacities, ownership of critical infrastructure) }\end{array}$ \\
\hline & Dependencies, such as need of inter-municipal collaboration \\
\hline & $\begin{array}{l}\text { Intra-organizational characteristics (organizational culture, } \\
\text { esprit de corps, adaptive management, bureaucracy) }\end{array}$ \\
\hline \multirow{13}{*}{ Regional network governance } & $\begin{array}{l}\text { Agenda (goal-setting, planning and policy) of the regional } \\
\text { network as a collective }\end{array}$ \\
\hline & Legitimacy, commitment and compliance \\
\hline & Rules of the game (institutional rules) \\
\hline & Leadership and control \\
\hline & Presence of a regional network organization \\
\hline & Experimenting \\
\hline & Arena of arenas with forum ('meta governance') \\
\hline & Formal mandate to act \\
\hline & Process- and network management \\
\hline & Establishment of a common language \\
\hline & Proximity \\
\hline & Policy instruments and 'mixes' \\
\hline & Membership of issue networks \\
\hline \multirow{6}{*}{ External factors } & Economic circumstances \\
\hline & $\begin{array}{l}\text { Context-specific characteristics of the region (like presence of } \\
\text { natural resources or industry) }\end{array}$ \\
\hline & Formal status of the region \\
\hline & Region's status as embedded in governance structures \\
\hline & Regional politics and policy priorities \\
\hline & Presence of energy plants and infrastructures in the region \\
\hline
\end{tabular}




\section{Research Design and Methodology}

The research design concerns an illustrative case study. The case study analyzed in this study is the West-Brabant region, that is situated in the province of North-Brabant in The Netherlands. Information on case selection, data collection, and analysis of the case study is presented below.

\subsection{Case Selection}

The West-Brabant region was selected for three reasons. First and foremost, the region was chosen as one out of five pilot regions in The Netherlands in which regional energy strategies were to be developed in 2016-2017. The pilots were initiated by the umbrella organizations of Dutch municipalities (VNG) and Dutch provinces (IPO) [73]. Second, relatively speaking, the West-Brabant region (from here on mentioned as ' $\mathrm{WB}^{\prime}$ ) is sizeable: it is home to 725,215 inhabitants and consists of nineteen municipalities (eighteen in the North-Brabant province, and one in the Zeeland province). Like many other regions WB contains a large urban center-the City of Breda (with roughly 182,000 inhabitants) —and a rural periphery that consists of many small- and medium-sized localities. The region also has a regional administrative body, 'Regio West-Brabant' (RWB), in which the nineteen municipalities collaborate, and jointly seek to foster regional socio-economic development (See Figure 1 for the location of West-Brabant within The Netherlands).

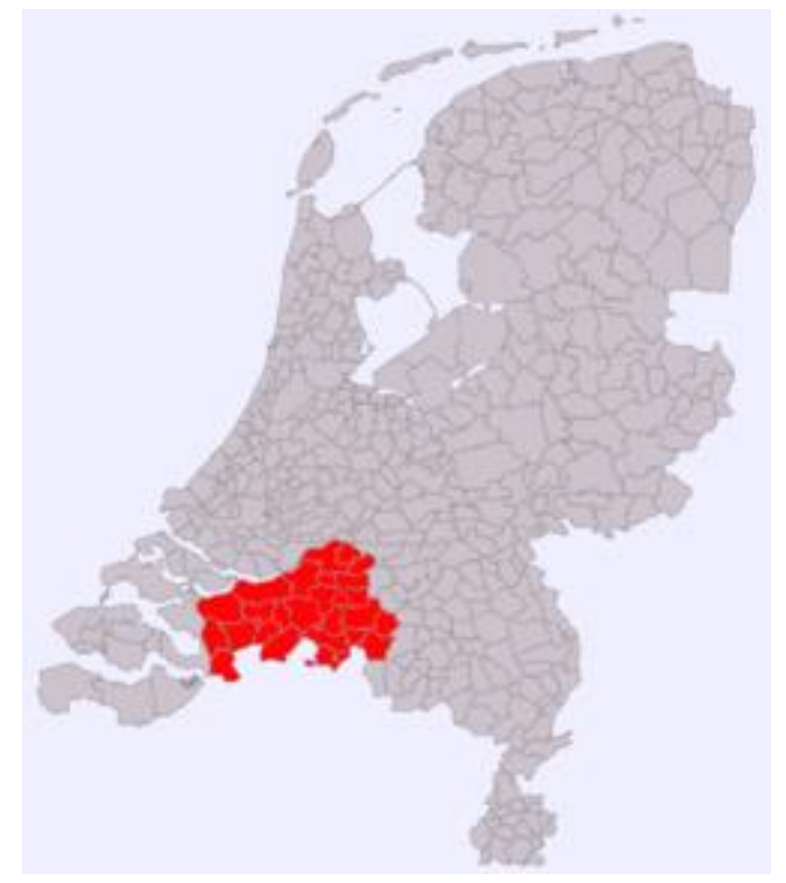

Figure 1. Location of the West-Brabant region within the confines of The Netherlands. (URL: $\quad$ https://nl.wikipedia.org/wiki/Politie_Midden-_en_West-Brabant\#/media/Bestand: Politie_Midden_en_West_Brabant_(Nederland_gemeenten_2009).png).

Third, WB is characterized by a relatively strong degree of inter-municipal collaboration. A study by Boogers and Klok [74] showed that inter-municipal collaboration in the North-Brabant province is relatively stronger than the national average in The Netherlands, and that WB is performing best on an number of indicators among regions within the North-Brabant province-for instance, in WB, $65 \%$ of collaboration forms has a public character (using the 'Wgr' arrangement), whereas the average in North-Brabant is only $58 \%$. When looking into the number collaborations municipalities have (in relative terms) WB municipalities have a $59 \%$ performance, whereas the Dutch average is merely $31 \%$, and the North-Brabant province average is $47 \%$. Municipalities in WB also outperform their peers in the province and the country in terms of perceived presence of a collaboration culture. For these 
reasons the WB region can arguably be seen as a frontrunner among other regions in The Netherlands in general, and the province of North-Brabant, more specifically.

\subsection{Data Collection and Analysis}

Data collection took place in 2018 and 2019. It included desk research of available text and online documents, twenty interviews, and participative observation. Face-to-face interviews (and one telephone interview) were conducted with professionals and stakeholders involved with RET. This included civil servants of municipalities, the Water Board, and the provincial government; engineers, researchers, consultants, members of community energy cooperatives, and managers employed by distribution grid operators and housing associations. Participative observation entailed participation in five meetings and workshops addressing RET in the built environment. This included sessions on 'energy transition in the region' (organized by 'Ruimtevolk' a creative consultancy office for urban and regional development), 'future-proof housing stock' (by RWB), a consultative body meeting of $\mathrm{RWB}$, and meetings by stakeholders seeking to prepare a grant proposal to achieve district renovation projects funded by national government.

Data collection activities intended to cover all relevant ongoing projects, but also sought to cover a variation of stakeholders in the WB region-for instance, not only were stakeholders from the urban center of the region interviewed (i.e., the City of Breda), but also stakeholders from municipalities in the peripheral area. This variation was also sought pertaining to multiple relevant levels of decision making (i.e., local, regional, provincial, national), and multiple sectors, like stakeholders from public sector organizations, the private sector (e.g., distribution grid operator), civil society (e.g., a community energy collective), and level of analysis, discerning between provincial level, regional level, local level and city district level (e.g., the latter pertaining to city district level renovation projects). An overview of the interviews conducted is presented in Table 2.

Collected qualitative data were analyzed by applying the conceptual framework on governance of regional energy transition (See Table 1 presented in Section 4). This was done by mapping key historic events relevant to energy transition in the WB region, covering both the strategic (regional) policy making level and the operational (local) project level. Key events and projects of RET in the WB case were identified, and put in perspective to each other. Consequently, an overview of RET and the governance thereof in the WB region was constructed. Having this information in place then allowed the researchers to reflect on the developments and key events using the conceptual framework presented in Section 4 as an analytical reference. Key events were then reflected upon using all elements of the framework, and addressing these on a point by point manner (i.e., in what ways did 'regional network composition' impact energy transition in WB?, or how did 'regional governance' impact energy transition in WB?). 
Table 2. Overview of interviews conducted in the West-Brabant (WB) case.

\begin{tabular}{|c|c|c|c|}
\hline Name of Organization & Type of Organization & Function of Interviewee & Date of Interview \\
\hline Ons 2050 & $\begin{array}{l}\text { Regional energy transition } \\
\text { support organization }\end{array}$ & $\begin{array}{l}\text { Chair and member of } \\
\text { executive organization }\end{array}$ & 23 May 2018 and 1 June 2018 \\
\hline Rabobank & Bank & Director & 23 May 2018 \\
\hline Wonen Breburg & Housing association & $\begin{array}{l}\text { Purchasing manager, } \\
\text { network manager, and } \\
\text { advisor sustainability }\end{array}$ & 25 May 2018 and 21 June 2018 \\
\hline Vrins Advies & Advisor & $\begin{array}{l}\text { Energy and } \\
\text { neighborhood visions } \\
\text { advisor }\end{array}$ & 28 May 2018 \\
\hline Alwel & Housing association & $\begin{array}{l}\text { Advisor rental affairs } \\
\text { and sustainability }\end{array}$ & 29 May 2018 \\
\hline Bergen op Zoom & Municipality & $\begin{array}{l}\text { Civil servant } \\
\text { sustainability policy }\end{array}$ & 30 May 2018 \\
\hline Energiek Brabantse Wal & $\begin{array}{l}\text { Community energy } \\
\text { cooperative }\end{array}$ & Chair & 30 May 2018 \\
\hline Energieloket West-Brabant & $\begin{array}{l}\text { Executive organization in local } \\
\text { energy policy }\end{array}$ & $\begin{array}{l}\text { Self-employed } \\
\text { entrepreneur }\end{array}$ & 1 June 2018 \\
\hline Energiecoöperatie Halderberge & $\begin{array}{l}\text { Community energy } \\
\text { cooperative }\end{array}$ & Chair & 1 June 2018 \\
\hline Regio West-Brabant (RWB) & $\begin{array}{l}\text { Regional governance } \\
\text { organization }\end{array}$ & $\begin{array}{l}\text { Program manager spatial } \\
\text { affairs }\end{array}$ & 5 June 2018 \\
\hline Gemeente Steenbergen & Municipality & $\begin{array}{l}\text { Alderman and policy } \\
\text { officer }\end{array}$ & 6 June 2018 \\
\hline AM ISearch & Consultancy & Advisor sustainability & 6 June 2018 \\
\hline Enexis/Enpuls & $\begin{array}{l}\text { DSO with business unit on } \\
\text { energy transition }\end{array}$ & $\begin{array}{l}\text { Strategic advisor energy } \\
\text { affairs }\end{array}$ & 11 June 2018 \\
\hline Ennatuurlijk & DSO heating grid & Account manager & 13 June 2018 \\
\hline $\begin{array}{l}\text { Bredase Energie Coöperatie } \\
\text { (BRES) }\end{array}$ & $\begin{array}{l}\text { Community energy } \\
\text { cooperative }\end{array}$ & Chair & 13 June 2018 \\
\hline Province of North-Brabant & Provincial government & Policy officer & 14 June 2018 \\
\hline Gemeente Breda & Municipality & $\begin{array}{l}\text { Policy officer of DH } \\
\text { systems }\end{array}$ & 15 June 2018 and 21 June 2019 \\
\hline Waterschap Brabantse Delta & Water Board & Senior policy officer & 15 June 2018 \\
\hline Woningstichting Stadlander & Housing association & Sustainability manager & 26 June 2018 \\
\hline
\end{tabular}

\section{Results}

\subsection{Case Study West-Brabant-Strategy Making, Key Events and Projects}

In this section, key events pertaining to the formation of RET strategy in the WB region and key regional energy transition projects are presented that can be seen as contributing to RET in the period of 2016-2018.

\subsubsection{Regional Energy Strategy Pilot West-Brabant}

In 2015 a Green Deal was agreed upon by the representative body of Dutch municipalities (VNG), the provinces (IPO), and the Water Boards (UvW) to organize pilots on Regional Energy Strategies in five regions within The Netherlands. One of these pilots would be situated in the WB region, based on an initiative set by the administrative Region of West-Brabant (RWB) and the representative body of Dutch Municipalities (VNG). The goal of the pilot was to develop and deliver a Regional Energy Strategy (RES), with the goal of the WP region becoming 'energy neutral' by 2050. The RES was set to entail a vision, a long term strategy, as well as a roadmap for short term actions [73].

Under the direction of a control group, different regional actors worked nine months on the RES West-Brabant in 2017. The control group consisted of actors from different spheres in society: government, business, education, and civil society, and comprised between ten and twelve persons. This included civil servants from RWB and several municipalities partaking in the RES development. 
In the end, by October 2017, the processes resulted in the development of a strategy and a report ('Ons2050'; in English: 'Our2050'; translation by the authors). It contained visions on opportunities and barriers to energy transition at the regional scale, with a focus on spatial dispersion and impact of future energy production and supply, and provided multiple insights relevant to energy transition at the regional scale [75]. However, the process did not produce a roadmap or implementation plan. When finalized, the definitive report was offered to the initiating partners of the Green Deal (VNG, IPO, UvW), the municipalities that participated in the RES development project, and RWB.

Not delivering the initially foreseen roadmap and implementation plan was to some extent related to the fact that RWB was subjected to a reorganization in 2018, that led to a strategic reorientation favoring economic, labor, mobility and spatial affairs issues over environmental and energy ones. In other words, energy transition was no longer considered a core theme, which meant that the regional energy strategy process would no longer be prioritized. As a consequence, RWB seized to launch new initiatives to provide a follow up to the RES-WB, neither providing an action perspective nor equipping a central implementation organization. Meanwhile, the control group RES WB seized activities as well. Follow up actions were to be considered by organizations individually, foremost at the local level (e.g., by municipalities, community energy initiatives, and business enterprises). However, in 2018 private sector actors (i.e., Enpuls, a subsidiary of a grid operator; the Rabobank, a bank firm; and Suiker Unie, a producer of granulated sugar) established a stimulation fund, in the trust 'Stichting Support Ons2050' to stimulate follow up actions.

\subsubsection{Amernet}

Amernet refers to a heating grid that gets its (residual) heat from the 'Amercentrale', a coal fired electricity plant located in Geertruidenberg, situated in the north of the WB region. The heat grid provides heat to up to 40,000 households, 500 business enterprises, and horticultural greenhouses in the Breda-Made area (but also to the Tilburg region, which is located just outside the WB region). It mainly supplies heat to dwellings in city districts that were constructed after World War II, and in the 1960s. The grid operator that owns and operates Amernet is Ennatuurlijk. Amernet was constructed in the 1980s by ENWA, which was then the energy utility of the City of Breda. Ever since Amernet has had multiple owners, and in 2014 it was finally sold to PGGM and Véolia, who were (jointly) succeeded by Ennatuurlijk. Currently, Ennatuurlijk has a heat supply contract with RWE, the (multinational) energy company that owns the Amercentrale in Geertruidenberg. This contract was set to expire in 2024 [76].

In 2016, RWE and Ennatuurlijk developed a vision on how to green Amernet, which was then skeptically received by public officials (aldermen) of the Cities of Breda and Tilburg, and resident committees of the housing blocks connected to the Amernet grid, who criticized it for not being ambitious enough. They argued that more could be done than merely co-firing the coal plant with (imported) biomass and using of residual heat from the nearby industry complex in Moerdijk. Within the Cities of Breda and Tilburg district restructuring assignments were made addressing the connection of social sector housing blocks to the Amernet heating network. However, during the negotiations between Ennatuurlijk and two of the Breda-based housing associations, a business conflict emerged concerning the costs involved in connecting the housing blocks to the heating network. When the negotiations between the grid operator and the housing associations ran into a deadlock the Cities of Breda and Tilburg intervened. They escalated the conflict to the provincial level (identifying the conflict as a problem that exceeds municipal jurisdictions), which led the Province of North-Brabant to take the assignment out of the hands of Ennatuurlijk, and issuing contract research into ways how the Amernet gird could be utilized in a better way.

This research assignment was finalized in 2016 and led to the publication of the 'Vision on the sustainability of the Amernet heat supply' report. This vision was to serve as stepping stone for the newly formed partnership 'Amernetwerk' that sought to green and expand the heat grid. This also pertained to locally distributed sustainable energy sources eventually replacing current (fossil) energy supply to the network. It presumed that the Amernet network was to become an 'Open' heat 
network, that would allow distributed energy producers to feed in heat of their own. On 18 January 2018 a covenant was concluded between the Province of North-Brabant, the four local jurisdictions the Amernet heating network traverses, the regional energy distribution grid operator Enexis, the housing associations, horticulturalists, and residents' associations.

\subsubsection{Linking Amernet to City District Renovation Projects: The Case of Hoge Vucht, Breda}

One of the city districts in which housing blocks were to be connected to the Amernet heat grid concerned the Hoge Vucht district in the city of Breda. Hoge Vucht is a typical, large-sized 1960s district, with over 22,000 residents and 10,000 homes. Of these, $60 \%$ are socially owned by housing associations. A neighborhood vision dating from 2012 that is in line with municipal district heating vision applies to it. The latter was initiated by the City of Breda, but its development involved collaboration with three housing associations, grid operators Ennatuurlijk and Enexis, business enterprises, tenants' interest groups, condominium associations, the community energy cooperative 'BRES', and external advisors. In 2016, the vision for Amernet was established with stakeholders (see the previous Section 6.1.2). For the Hoge Vucht district this included the option to eventually expand the heat network, for instance to connect homes that were initially connected to the natural gas grid, but whose owners would opt for connection to the Amernet heating grid. Subsequently, a neighborhood energy plan was drawn from the performance agreements between the City of Breda, the three housing associations, and the tenants' interest associations. The plan consisted of a phase-wise development process, a participation plan and an implementation plan. The first result, the sustainable renovation of the 'Moerwijkzicht' multistory building with 241 dwellings connecting to the heating network was realized in the Spring of 2018.

This was quite an achievement, because at first the housing associations and the grid operator Ennatuurlijk disagreed on the terms and costs for heat supply from the Amercentrale. The housing associations argued that the tariffs the grid operator wanted to charge would increase tenants' living costs to an unacceptable level. From this perspective, housing associations were seriously weighing the alternative not to connect to the Amernet heat grid, and to install individually gas-fired heating boilers in the dwellings of the designated housing blocks. However, (as mentioned in the previous section) the City of Breda intervened, which led to substantively changing of the plans (at a stage in which project implementation was already carried out). Due to reaching a broad regional agreement on the future and sustainability of the Amernet, and the recalculation and adjustment of the connection tariffs, the housing associations could be persuaded to connect to the Amernet heat grid. In addition, consultation and supervision led to consent among the residents for connecting their homes to the heating network.

The approach to the Moerwijk multistory building renovation had subsequently evolved into an example for the next steps in the Hoge Vucht district, which was set to (entirely) disconnect from the natural gas grid, and hitherto connect to the Amernet heat grid. In this phase of the project, creating support and acceptance among the residents was critical. To achieve this, the project team worked together with 'ambassadors' from the neighborhood target group (e.g., street and floor contact persons), that also included the organization of participatory workshops so that residents were enabled to have a say. The neighborhood approach included engaging in dialogues with residents and initiating a process of creating awareness and support. The community energy cooperative 'BRES' played an important role in engaging tenants and homeowners seeking to unburden and persuade them. The City of Breda facilitated public participation in the process by organizing participation for the residents at the project, apartment complex, street and neighborhood level. However, financial means to support this turned out to be limited, which meant that the actors involved required additional funding to continue this approach. One way to do this was by submitting a subsidy application to the Ministry of the Interior for participation in the 'Gas free neighborhoods pilots call'. However, in Autumn 2018 it turned out that the subsidy application had not been granted. Another heating project in the neighboring municipality of Drimmelen had been funded instead. This case is noteworthy because it presents a heating grid that was to be developed and exploited by a citizen-led energy cooperative and would feature just the second of its kind in The Netherlands [77]. 


\subsubsection{Windpark A16}

As a regional follow up to agreements made between national government and the Province of North-Brabant, RWB made an enquiry at the regional level to map locations to generate renewable energy from wind sources. This led to designating several locations across the A16 highway (from the Belgian border in the southernmost part of the WB region to the 'Moerdijk' bridges—at the Hollandsch Diep influent-in the North) that would have the potential to have a capacity of up to $100 \mathrm{MW}$. Planning of a wind park at the site of the A16 highway was initiated by the Province of North-Brabant, together with four municipalities (Zundert, Breda, Drimmelen and Moerdijk; representing the municipal jurisdictions the highway traverses) that designated the area as fit for development and exploitation of wind energy. In 2015, the municipalities and the province formally concluded a covenant on the development of the A16 wind park.

Plans were elaborated by the province in close collaboration with municipalities and project developers, who had shown an interest in ground positions next to the highway. In 2017, the parties concluded a Green Deal agreement with the representative body of residents living nearby the designated areas regarding the development and construction of the wind parks. Plans were made to realize the A16 wind park by 2020 . To make this possible, the project team actively engaged stakeholders in the designated areas. This allowed several village and neighborhood councils to voice their views and worries vis-à-vis the project plans. In addition, they formed a sounding board. This was done to safeguard participation and interests of local communities, and to take away the initial resistance to the wind park pertaining to horizon pollution and several forms of perceived nuisance. An important characteristic of the Green Deal pertained to concluding local energy agreements with stakeholders like community energy cooperatives and other local civic-led collectives.

An important principle used concerned the so-called 'village mill principle', which meant that villages and neighborhoods surrounding the project areas should essentially benefit from the power generated by the nearby wind park. To adhere to this principle the four municipalities and the province made an agreement with the (commercial) project developers that at least $25 \%$ of the profits made by wind park exploitation should be awarded to adjacent local communities. This would compare to supplying (green) power to $18,000-24,000$ households. The planning of the wind park project also required an environmental impact assessment. When this was to be performed participatory consultation rounds and negotiations with citizens were organized as well. The project team actively engaged local stakeholders to enable them to voice their needs, ideas and worries. According to a spokesman of a local citizen cooperative the use of the 'village mill principle' was received well as it benefits local interests. This helped to frame project development in terms of being seen as less disruptive, causing less nuisance and local communities wanting to take care of the wind turbines because they are (partly) owned by the local community. The Province of North-Brabant provided financial support for project development, the participatory processes, and the future exploitation of the A16 wind park.

\subsubsection{Klimaattop Zuid}

In order to raise awareness of the issue of climate change, a top meeting for different sorts of actors in the three southernmost provinces of The Netherlands (Zealand, North-Brabant, and South Limburg) was organized in Breda on 4 June 2018. It was initiated by the think tank 'Brabantkennis', the City of Breda, and the Water Board 'Brabantse Delta'. Like-minded pro-climate actors organized themselves in 'Klimaatstroom-Zuid' a platform and movement that operated as network agent (i.e., as 'connector') and catalyzer of regional sustainability, actively supporting exchange of ongoing sustainability initiatives and projects. Part of the platform's manifesto was to attain RET goals, inviting stakeholders to endorse and support them. This manifesto was also used to convince newly formed municipality government coalitions to adopt energy transition goals in their coalition agreements, and hence local programs. On 4 June 2018, the top meeting was attended by representatives of 80 public organizations, 100 civic organizations, and 130 business enterprises. It resulted in actors 
making agreements on how to speed up efforts to foster energy transition (and in addition efforts pertaining to climate change adaptation), and laying the foundation to prepare an action program (i.e., 'Actieprogramma Klimaatstroom-Zuid'), that was to be concluded in the fall of 2018. This program was later presented to the Dutch national government in an effort to garner financial support. According to officials of the City of Breda and the Water Board 'Brabantse Delta' the attention and 'success' of the top meeting strengthened the collaboration between local and regional parties on the one hand, and ties with the Province of North-Brabant on the other hand.

\subsection{Results of the Reflective Regional Network Governance Analysis}

Compared to most other regions in The Netherlands and its surrounding regions, the WB region, is relatively big, not only in terms of geographical scope but also in terms of differences between actors, particularly municipal organizations that differ in size, capacity and degree of knowledge. The region features both the presence of space and industrial residual heat capacity, but wind and solar projects seize valuable space and have a big impact on the landscape, which are bound to raise opposition. Although RWB is present as an inter-municipal administrative entity (with formal authority in a number of policy domains, but not in the domains of energy and sustainability), the governance structure on energy transition in the region is very polycentric with decision making taking place at provincial level (i.e., the Province of North-Brabant), the regional level (RWB, 'Ons2050'), and several local and sub-regional decision-making centers, some covering multiple municipal jurisdictions, also in project-based settings centered around infrastructural project development, like the A16 wind park or the Amernet heating grid (See Figure 2 for a graphical depiction of this layered polycentric decision making). Actors involved in these projects are predominantly regime insiders (like the provincial government, energy suppliers, DSOs, project developers, and property owners) but also feature some regime outsiders (like community energy collectives).

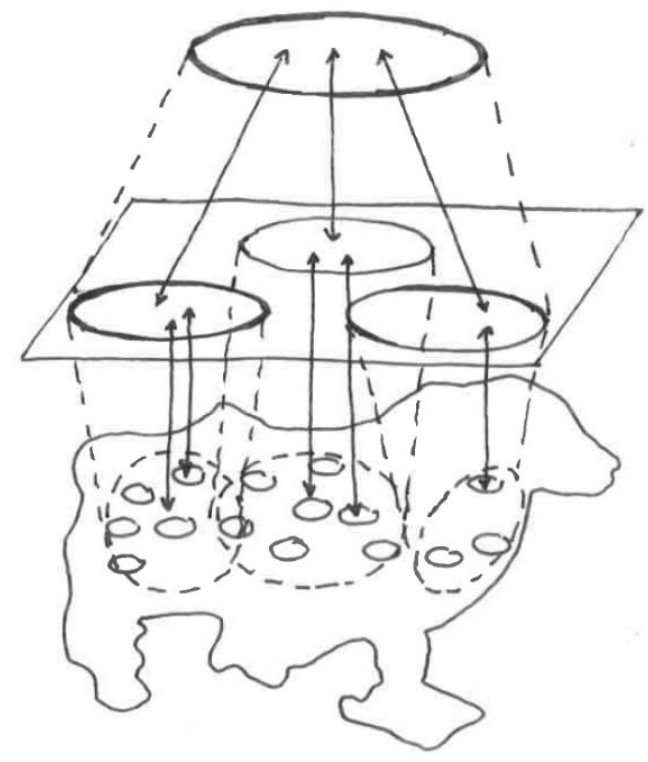

Figure 2. Graphical depiction of layered polycentric decision making in the WB case [78].

When reflecting on successful action in the region, many projects involved the City of Breda, which is not surprising given the long history the city has a progressive pro-environmental frontrunner in The Netherlands, and the capacity it has in terms of staff facilitating policy implementation of low carbon policy and action. While the City of Breda has been actively engaged in climate change mitigation policy for years [79], and is even home to one of the largest solar parks in The Netherlands, this can hardly be said for the smaller-sized municipalities in the rural hinterland of the WB region. 
Not only do they lack capacities, they also lack political and administrative priority setting, as energy transition goals have hardly been adopted in municipal coalition agreements and visions.

Regarding the capacity problem, it is not only municipalities that report this problem, but also other actors like energy suppliers, regional grid operators and housing associations who claim that lack of educated, skilled staff limits their operations in energy transition projects. In addition, they report lack of organizational capacity and lack investment capacity, which in turn leads these organizations to show little support vis-à-vis challenges in RET, and do not actively collaborate with each other.

A lack of involvement from the business sector and knowledge institutes contributes to capacity problem. This indicates a lack of interaction between these subs-systems and those of decentral governments and energy suppliers who are involved in RET in the WB region. Because of these problems, however, municipalities observe dependency toward parties that are better off in terms of capacities. In WB, most municipalities welcome the idea of more inter-municipal collaboration. However, the City of Breda-as only urban center in a polycentric region that exists of smaller municipalities-showed to be less fond of strengthening regional collaboration ties, and to rather pursue continuation of (intensive) collaboration with higher tiers of government.

Another central actor in the WB case is the Province of North-Brabant. In the large-sized infrastructural project covering multiple municipal jurisdictions-i.e., the A16 wind park project development and the Amernet heat grid expansion project- the provincial government took on important roles to facilitate progress. In the A16 wind park case, it initiated the project, and actively (also financially) supported project development, participatory processes, future exploitation, and concluding a covenant (2015) and Green Deal (2017) with other stakeholders. In the Amernet case, the provincial government intervened when the Cities of Breda and Tilburg escalated a problem between grid operators and housing associations, that led to depriving the grid operator of authority and moving them to a broader coalition of actors. The province then established a steering group, ordering research, and hiring process managers and network managers. In 2018, the province also concluded a covenant in the Amernet project. Although the provincial government succeeded in taking leading roles in these processes it was also criticized for taking a more prominent central role in the policy making process of energy transition in the WB region. Interviews revealed that although public officials were keen to put RET more firmly on the agenda this turns out to be difficult as the (provincial) organization is perceived as stuck in traditional, institutionalized structures, while the current regulatory framework and policy instruments available only offer poor relief in terms usability and anticipated effectiveness. Moreover, spatial policy frameworks require the provincial government to first develop an Environmental Vision ('Omgevingsvisie' in Dutch; translation by the authors), which can then be used to draft an Environmental Ordinance ('Omgevingsverordening' in Dutch; translation by the first author), which can eventually be enforced when implemented.

Whereas WB performs generally well as a region in terms of regional inter-municipal collaboration (Boorgers and Klok, 2016), this is not evident from in the RET case. First, the RWB administrative body took an innovative and daring endeavor when participating the pilot 'Regionale Energie Strategie West-Brabant', as one out of five pioneering regions in The Netherlands. Innovative pilots like these can be considered (energy) transition experiments (Loorbach and Rotmans, 2010). When the pilot started, a management body was set up to facilitate the RET development process. However, this body was deprived of a formal mandate, was not assigned a financial budget, nor was it allowed to have any decision-making power of itself. This limited its strategy forming and operations and deprived it of the possibility to become more of regional network organization. While RWB managed to publish a vision document ('Ons 2050'), this was not followed by the establishment of an executive organization that would coordinate planning and implementation of the RET (something that did occur in other regions where similar pilots were organized, like 'Hart van Brabant' and 'Drechtsteden'). A reason for this was that municipalities held differing perceptions about the mandate and directions of the regional energy strategy assignment. 
Moreover, initial optimism and commitment among regional actors eventually faded into skepticism and stagnation, which in turn led to poor compliance of agreements made, and few concrete actions taken (for instance among renewable energy communities). Interviewees argued that in hindsight agreements were too much depending on voluntary action and goals were considered to have an open-ended character. Moreover, energy transition was no political priority in the region at the time because politicians did not dare to openly address its consequences (regarding spatial and financial-economic impact). Other reasons contributing to the poor follow up of the strategy document concerned uncertainties about the supportive policy framework offered by the national government, following ongoing debates about drafting of a program, instrumentation and blueprint guidelines. In addition, interviews revealed that regional parties considered the provincial government too much 'at distance' of local decision making arenas (i.e., in terms of proximity). This pertained to both geographical distance and institutional distance of provincial government which was considered hardly capable of dealing with regional-specific, situational matters.

In the absence of regime actors adopting the RET implementation, an institutional newcomer arrived: the Water Board 'Brabantse Delta', a functional regional government entity on water governance, but also energy supplier (via processing of sewage sludge into biogas), which sees a role for itself as governing RET governance processes for the reason that it wants to pursue a more prominent role in regional climate policy, covering both adaptation (which it already addresses from its traditional water governance portfolio), and mitigation (i.e., regional low carbon energy transition). The Water Board can arguably be perceived as a 'regime outsider' seeking to gain control in a new policy domain, and also highlights a rare occasion of subsystem interaction in the field of energy transition, traditionally reserved to more traditional energy domain actors.

Another case of regime outsider involvement pertained to municipal and provincial governments engaging community energy cooperatives (as civil society actor) with the latter taking different roles. First, as participants and co-creators in the strategy and vision development of the RES WB pilot. Second, as target group and intermediary involved in convincing local communities living nearby the foreseen A16 wind park, using the 'village mill principle' to redistribute part of the financial gains made by future exploitation of the wind turbines to local communities, arguably a social innovation. And third, as co-producing actor to facilitate local participatory processes in neighborhood heating grid expansion project like Hoge Vucht.

From a network management perspective, the Klimaattop Zuid event can be regarded as a venue to attain connections to actors that were not yet connected, to synthesize subsystem interaction, and (perhaps most importantly) to gain public legitimacy. The platform initiating and organizing the event can be viewed as a 'connecting' network manager (which may also apply to the Province North-Brabant and the Water Board 'Brabantse Delta' supporting the platform in this endeavor). After gaining legitimacy, the platform 'Klimaatstroom Zuid' expressed the intention to contribute to RET in West Brabant by setting up a stimulation fund, preparing an action program that would include getting more actors involved, gaining more commitment from actors for the regional challenge, deploying financial and knowledge capacities and to foster regional collaboration. By doing so, it would potentially fill the void left behind by RWB when it dropped the desire to set up an executive body to implement the RET strategy presented in the 'Ons2050' document.

Figure 3 presents a layered diagram of key actors, key events, key projects and the main policy instruments used in the WB case. It distinguishes between the local level, the regional level, the provincial level, and the national level. 


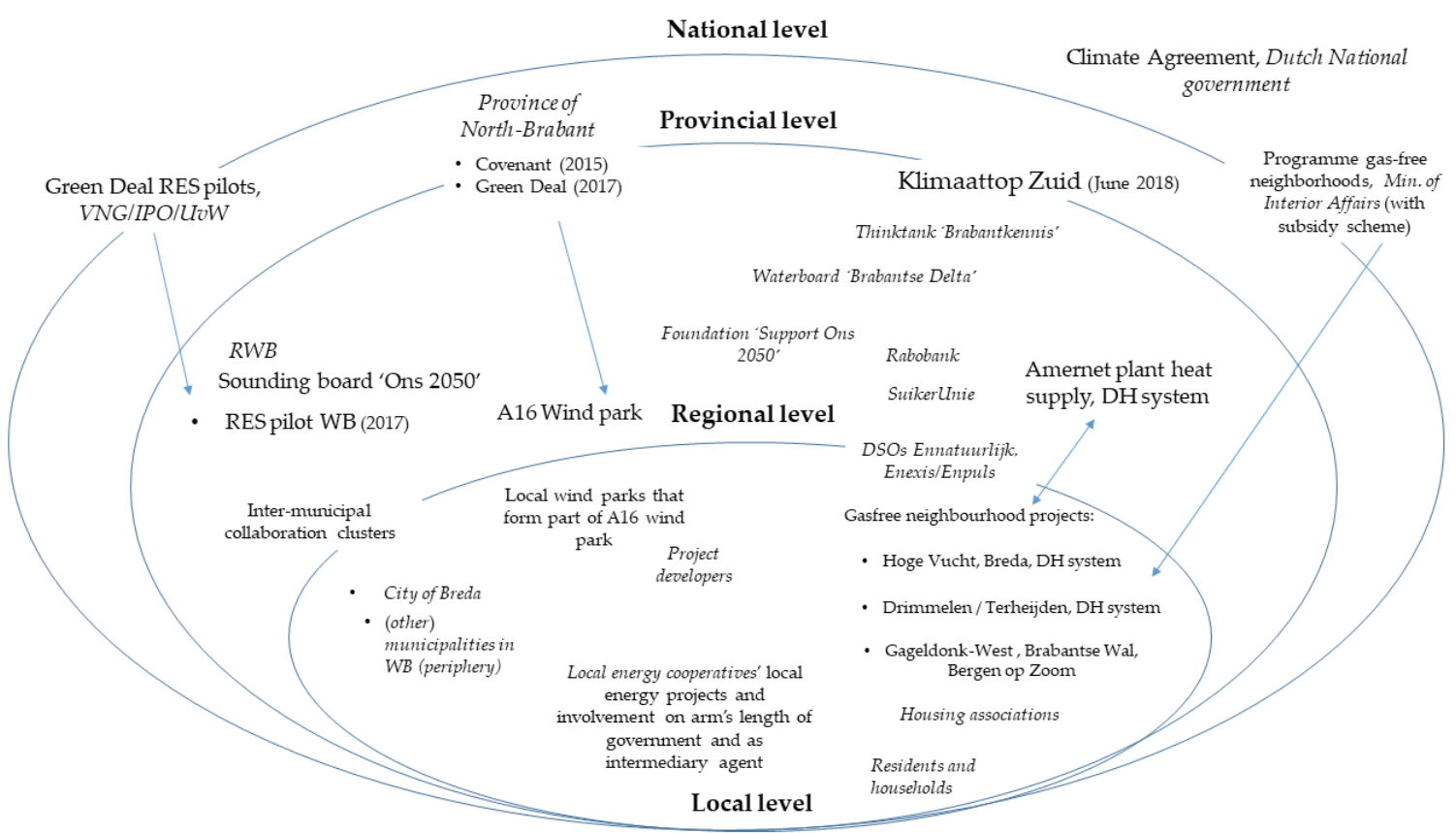

Figure 3. Overview actors, events, projects and policy instruments of the WB case presented per geographical level.

When looking into policy instruments used in the West-Brabant regional energy strategy actions, key instruments were Green Deals, covenants, and the top meeting. The most important Green Deal obviously concerned the pilot 'regional energy strategy' (2016) that facilitated and mobilized regional actors to engage with the RES formulation in the first place. Given its novelty (being one of the five regional pilots in the country) it arguably had somewhat of an experimental character (although regional collaboration between actors already occurred in many other policy domains). Other Green Deals established in the WB case pertained to those involving local stakeholders on the development and construction of the A16 wind park, also being aligned with local energy agreements and participatory trajectories (also in relation to legal mandatory environmental impact assessments). Covenants were mostly established in projects involving multiple municipal jurisdictions and with a high degree of multi-actor complexity (and in that sense they can rightfully be addressed as regional projects), like the 2015 A16 wind park development covenant and the 2018 Amernet covenant. They were typically used to cover cross-jurisdictional issues between actors acting at the provincial or regional level on the one hand, and actors acting at the local level on the other. Finally, the top meeting 'Klimaattop Zuid' event was organized to raise awareness and gain legitimacy for RET among a large number of actors. It should be noted though that the policy instruments used were not limited to the Green Deals, covenants and top meeting, but also included the likes of feed in tariff, spatial permits, zip code rose applications (to stimulate collective renewable energy generation projects; Kooij et al., 2018), environmental permits, and (a variety of) subsidy schemes. However, they have a more general character, and are applied to the local, district or household level.

Table 3 presents a summarizing overview of how the WB case performed against the conceptual framework on governance of RET. 
Table 3. Overview of how the WB case performed against the elements and items of the conceptual framework of governance of RET.

\begin{tabular}{|c|c|c|}
\hline Theoretical Factors of the Analytical Framework & Presence in WB Case & Influence on RET in WB Case \\
\hline \multicolumn{3}{|l|}{ Regional Network Composition } \\
\hline Actor membership and heterogeneity & Moderate, but increased & Fairly positive \\
\hline Scope (multi-level, multi-sector) & Moderate, but increased & Moderate \\
\hline Involvement of regime outsiders & At first rather low, but increased & Fairly positive \\
\hline Interaction with incumbents & Fairly strong & Moderate \\
\hline Interaction of subsystems & Relatively weak & Fairly negative \\
\hline History of network actor interaction & Strong & Moderate \\
\hline Culture of interaction & Fairly strong & Moderate \\
\hline \multicolumn{3}{|l|}{ Actor Characteristics } \\
\hline Motivation and goals & Moderate, but decreased & Negative \\
\hline Cognition & Relatively weak & Negative \\
\hline $\begin{array}{l}\text { Access to and ownership of resources (e.g., competences, } \\
\text { knowledge, capacities, ownership of critical infrastructure) }\end{array}$ & Relatively weak & Negative \\
\hline Dependencies, such as need of inter-municipal collaboration & Moderate & Moderate \\
\hline $\begin{array}{l}\text { Intra-organizational characteristics (organizational culture, } \\
\text { esprit de corps, adaptive management, bureaucracy) }\end{array}$ & Negative & Negative \\
\hline \multicolumn{3}{|l|}{ Structural Characteristics of the Regional Network } \\
\hline Size & Fairly large & Fairly negative \\
\hline Degree of complexity & Fairly complex & Negative \\
\hline Polycentricity & Fairly complex & Moderate \\
\hline Cohesion & Fairly strong & Moderate \\
\hline Presence of clusters, sub-networks and coalitions & Presence of a fair amount of clusters & Moderate \\
\hline Weak ties to other networks & Fairly strong & Fairly positive \\
\hline \multicolumn{3}{|l|}{ Regional Network Governance } \\
\hline $\begin{array}{l}\text { Agenda (goal-setting, planning and policy) of the regional } \\
\text { network as a collective }\end{array}$ & Progressive, but decreased & Negative \\
\hline Legitimacy, commitment and compliance & Fairly poor & Negative \\
\hline Rules of the game (institutional rules) & High degree of institutions present & Fairly negative \\
\hline Leadership and control & Moderate, but decreased & Fairly negative \\
\hline Presence of a regional network organization & Moderate, but decreased & Fairly negative \\
\hline Experimenting & Fair degree of experiments undertaken & Fairly positive \\
\hline Arena of arenas with forum ('meta governance') & Poorly developed & Negative \\
\hline Formal mandate to act & Absent & Negative \\
\hline Process- and network management & $\begin{array}{l}\text { Present at local level, ceased to exist at the } \\
\text { regional level }\end{array}$ & Fairly negative \\
\hline Establishment of a common language & Poorly developed & Negative \\
\hline Proximity & Perceived as high proximity & Fairly negative \\
\hline Policy instruments and 'mixes' & $\begin{array}{l}\text { High degree of third generation instruments } \\
\text { used. Poor use of economic instruments }\end{array}$ & Fairly negative \\
\hline Membership of issue networks & Fair amount of memberships & Fairly positive \\
\hline \multicolumn{3}{|l|}{ External Factors } \\
\hline Economic circumstances & Positive & Moderate \\
\hline $\begin{array}{l}\text { Context-specific characteristics of the region (like presence of } \\
\text { natural resources or industry) }\end{array}$ & Fairly strong & Positive \\
\hline Formal status of the region & $\begin{array}{l}\text { No official status to Regional Energy } \\
\text { Strategy }\end{array}$ & Negative \\
\hline Region's status as embedded in governance structures & Relatively poor & Fairly negative \\
\hline Regional political and policy priorities & Moderate, but decreased & Negative \\
\hline $\begin{array}{l}\text { Presence of energy plants and infrastructures in the region } \\
\text { (e.g., for use of residual heat) }\end{array}$ & Present & Positive \\
\hline
\end{tabular}

\section{Discussion}

The analysis using the conceptual framework to analyze the WB case revealed that although the WB region enjoyed a rather favorable starting situation, with fairly positive external factors as well as fairly positive structural characteristics of the regional network, it encountered challenges in the areas of actor characteristics and regional network governance. The conceptual framework aided in structuring the analysis and revealing strengths and weaknesses in the WB RET case and gaining insights in the complex practice of RET and approaches to govern it. 
When reflecting on the WB case from a systemic perspective, sufficient regional systemic structure was absent, which was shown by the lack of strategy and coordinated action, although inter-municipal collaboration is traditionally relatively strong in WB. In contrast, it is rather a relatively high degree of situational polycentric decision making that takes place, and which applies to both the geographical and multi-level government dimensions. Moreover 'sphere' interaction-as addressed by Mattes et al. [14] — was limited, with little involvement from the business and education sectors. Neither were there firms taking lead roles, and strategic action was foremost government-led (i.e., RWB, Province of North-Brabant, and City of Breda), fragmented and highly situational. In sum, conditions for RIS were not met [25] with hardly any innovative nor transformative capacity present in the WB region.

'Policy mixes' retrieved in the cases revealed a comprehensive picture, but also showed the need for particular instruments like Green Deals and covenants to deal with the innovative and comprehensive nature of regional energy project covering cross-jurisdictional boundaries in complex multi-actor settings (e.g., in the A16 and Amernet cases). Perhaps, it is fair to state that comprehensive 'policy mixes' were required to deal with the lack of systemic innovation structures regarding energy transition in the WB region, arguably as new governance arrangements, social innovations $[15,80]$, or even 'proto-innovation systems' [21].

Barriers encountered to RET in the WB case revealed few that were also coined by Lutz et al. [26], viz. challenging (and changing) political priorities, complaints by participants in the process, unexpected costs, and considerable differences between municipalities prioritizing and engaging in energy transition activities. The latter also appears related to large-sized municipalities having more capacities and progressive pro-environmental policies in place $[69,70]$. In addition, proximity of decision-making authority was considered problematic. Interviewees voiced a need for governance at the sub-regional level to allow for increased proximity of government to pay more attention to situational circumstances. This observation is in line with Boschma [19] who argues that proximity of government and decision making is important to foster regional innovation.

In line with Lutz et al. [26] the WB case also revealed that sound process management and strong engagement in formal networks are important pre-conditions to RET. The latter also hinges upon the establishment of a regional scale transition arena—as proposed by Loorbach and Rotmans [34] - to set up a deliberation forum and act as (meta) arena of (sub) arenas. However, in hindsight two attempts to do so were undertaken in the WB region. First, RWB partaking in the RES pilot establishing a regional arena to draft a regional strategy but failing to materialize into an executive body to monitor and coordinate operations. Second, the 'Klimaatstroom-Zuid' platform setting up a stimulation fund and calling for an 'action program' (however, for the three southernmost provinces of The Netherlands, and not only the WB region). In sum, both reflected promising initiatives, but did not materialize into any actual transition arena.

What neither helped was the lack of a formal mandate (a factor that is often positively related to regional governance performance [41]), and the absence of any legitimate RET document. Moreover, many of the conditions to run regional transition processes assumed necessary by Loorbach and Rotmans [34] were never met in the WB case. The only serious attempt to do so failed, which led to a situation in which sub-regions hardly interacted, with projects developed at the sub-regional level, which were clearly rooted in local project arenas (like the regional Amernet project connecting to the local Hoge Vucht project). This is in line with the notion Fuchs and Hinderer [63] who hold that a variety of actors are involved with different aims and interests, to go with the development of space-specific technological mixes culminating in situational governance structures. The WB case showed that these governance structures are not necessarily restricted to the local level, but also address renewable energy and heat grid infrastructure projects that cross municipal jurisdictions. It also showed the importance to get higher levels of government involved (i.e., the Province of North-Brabant) as well as experienced local governments with high capacities (i.e., the City of Breda). In that sense embeddedness in existing governance structures can be considered of great importance (See also [3]). 
Looking at cities as loci in regions in which the dynamics and interplay between urban and rural is considered important [66] the WB case reveals that cities like Breda have an important function, but that their administrations are not overly enthusiastic to engage in regional affairs. On the one hand, this particular city could be seen as a frontrunner and as a process manager supporting regional projects. On the other hand, it also tried to fend off engaging too much in intensive formal regional governance structures with smaller localities in the rural hinterland (having different, less progressive agendas, while lacking multiple capacities). This phenomenon in RET does not stand alone. It is also observed with larger scale cities that are active in regional governance pertaining to other policy domains [41].

In line with De Leeuw and Groenleer [15] the WB case showed that regional governance processes take place in the shadow of policy developments at the national level, and even to the extent that ongoing negotiations in policy making at the national level create a high degree of uncertainty. This leads to inaction at the regional level with stakeholders refraining from action because they perceive high uncertainty with regard to the key future policy instruments that will eventually be introduced, and the consequences this will likely have on the level playing. Therefore, it is probably fair to state that national government has an influential role in setting the agenda of RETs [15].

When reflecting on the role community energy initiatives have in RET the WB case revealed different perspectives. First, it showed that when invited to partake in regional energy strategy making community energy initiatives showed remarkable interest and commitment. However, the case also showed that community energy collectives were less eager to comply to agreements made with other regional stakeholders. Second, the case showed that community energy initiatives actively engaged in projects like the A16 wind park and Hoge Vucht acting as intermediary parties, often targeting persuasion of local community households, and gaining legitimacy in support of the renewable energy and district heating projects. Arguably, they acted well in taking on the role of intermediary in local energy projects [72], acting on arm's length of government, co-producing awareness and support for local energy projects among local communities [16].

In sum, for regional actors to engage in RET is something new. RET can arguably be seen as a policy experiment seeking ways to form new governance arrangements and test whether and in what forms they work out well in terms of becoming legitimate and effective policies that contribute to both carbon reductions as well as to welfare and wellbeing of regional residents and stakeholders. Shaping, implementing, evaluating and re-shaping RET governance, however, requires a great deal of commitment, time and (structural) attention. Based on observations in the WB case it should not expected that an RET approach will be effective when only a regional audit is performed, a vision is developed, and the regional actor network dissolves afterwards without further embedding in an organizational body or network that has the will and capacity to plan and implement the strategy formed.

From a transition theory perspective [28], this can be perceived in different ways. First, the actors involved were particularly incumbents with regime outsiders only involved in passive ways (rather than in active decision making or co-design) on arm's length of government or in local projects of their own. Second, in contrast to the Parkstad case [34] no actual 'TM' approach or anything like it was undertaken. While the regional government RWB, some municipalities, community energy initiatives, DSOs and a regional bank were involved this could by no means be perceived as a transition arena, excluding options on joint learning, development of joint solutions or actual co-creation. Moreover, after a year the RET team had already dissolved. Third, it is not clear whom the frontrunners or change agents were in the WB case. Arguably, the City of Breda, community energy collectives like BRES and Water Board Brabantse Delta have a few frontrunner persons in their organizations, but they were no active part in setting up the RET strategy. It looks like frontrunners were scattered across the region, and did not cohesively or actively partake in tactical decision making at the regional level. Fourth, it is up for debate whether RET can be perceived as an (social, governance) innovation and can be seen as a niche in itself. If yes, in what ways do regimes manifest and form barriers that prevent RETs from taking place? Arguably, regime barriers can be found in the case of making the Amernet energy plant 
more sustainable (and its supply of heat via DH systems), challenges that were encountered during the siting and planning of the A16 wind parks, and attitudes of civil servants and political officials of the provincial and local governments.

\section{Conclusions}

This paper set out with the following research questions: "What does governance of regional energy transition entail? How can it be conceptualized? And what does it mean in practice?" Based on a literature study with studies from the disciplines of regional innovation studies, transition studies, and governance studies (the latter also addressing the elements of regional governance of issues in other domains, with a theoretical focus on network governance), a conceptual framework was conceived. This framework consists of five clusters: structural characteristics of the regional network, regional network composition, actor characteristics, regional network governance, and external factors. To increase understanding in governance of regional energy transition (RET) in a practical situation the framework was applied to the illustrative case of the West-Brabant region in The Netherlands.

The West-Brabant case presented a case study in which agenda setting set off ambitiously and in a promising way. After the initial start-orchestrated by a regional administrative entity-was successful leading to a visionary document, developments halted when regional priorities shifted, and the collective failed to establish a structure for institutional continuation and implementation of RET. Notwithstanding, regime outsiders, newcomers to the policy network-a Water Board and an NGO-fueled the initiative to carry on, but on a more voluntary base, while lacking a formal mandate. The WB case study revealed the relevance of each of the five elements of the conceptual framework.

However, some were of particular relevance. This particularly holds for structural characteristics of the network (i.e., the provincial government having an important role as intermediary actor and as facilitator), regional governance (i.e., RET governance is challenging, especially in the absence of a leading actor with a formal mandate to govern; moreover RET is no political priority), and actor characteristics (i.e., municipalities lacking capacities to follow up in RET governance). Nonetheless, external factors like dependency on national government setting policy arrangements, and regional political and administrative priority setting were also influential, more particularly in the sense that they limited progress in regional energy transition agenda setting. A key take from the results of the case study is that RET governance shows commonalities with regional governance in other policy domains-for instance, decision making has a very polycentric character and the region's main city is involved in most of the key regional projects. However, public officials of this city's administration are not fond of engaging too much in regional collaboration, which is unlike peers in the peripheral areas of the region.

Although the case study presented insights in the practice of governance of regional energy transition, this should be understood with caution. Limitations to the study pertain to the case selected and data collection. First, the WB region is by no means a case that should be easily generalized to other regions in Western Europe for the reasons that WB can be seen as a frontrunner because it was part of a pilot program to develop regional energy strategies, and that the region is a high performer in terms of regional, inter-municipal collaboration (even countrywide). The fact that the locus of the study was The Netherlands might also reflect selection bias because of the country's corporatist negotiation culture (with the so-called 'polder model' of decision making by reaching consensus), which favors non-hierarchical, networked forms of governance. Regarding data collection, it should be noticed that data collection was restricted to a period of two years after the pilot regional energy strategy WB had started. So, only two years had passed since initial planning of the regional strategy. In that sense, it would be interesting to study a region in which structural energy transition strategy, planning and implementation has been going on for a longer period-for instance, at least five years. At the time of writing this was not possible in The Netherlands since the first pilot regions only commenced three years ago. Another limitation concerns the fact that interviews conducted and participation in 
meetings were selective, and that the research might have missed out on key events and projects in the region, in addition to the ones that were observed within the present study.

For future research, we suggest that studies apply and elaborate the conceptual framework on governance of RET as presented in the present paper using other regional case studies. Future research might also want to tap into comparing RET governance to the emergence of regional governance in other complex policy domains (e.g., safety, health care, or environmental policy enforcement). To achieve a more representative view of what regional energy transition governance looks like, it is worthwhile to select and analyze other-preferably multiple — case studies of regions, varying by nation, in terms of key economic activity, and in terms of engagement in networking, and history with regional governance. In addition, it would be worthwhile to study the experiences and perceptions of public officials of decentralized governments with regard to governance of sustainable transitions at the regional level. For example, by interviewing them or by conducting a survey to derive more general, statistical representative results, and to reveal commonalities and patterns. Alternatively, a survey can be conducted among regional stakeholders and citizens on how they perceive governance of regional sustainable transition by decentralized governments. In addition, it would be interesting to study RET from a transition theory perspective to analyze the interactions between niche, regime and landscape of a RET case study. When addressing the niche level it would for example be recommended to analyze the role and agency of community energy in RET. Last but not least, it might be worthwhile to explore how studies on governance of RET would contribute to the expanding literature on polycentric governance of climate change [2].

Author Contributions: Conceptualization, Thomas Hoppe; methodology, Thomas Hoppe; analysis, Thomas Hoppe and Michiel Miedema; data collection, Michiel Miedema and Kasper Harteveld; writing-original draft preparation, Thomas Hoppe; writing — review and editing, Thomas Hoppe; visualization, Michiel Miedema and Thomas Hoppe; supervision, Thomas Hoppe; funding acquisition, Michiel Miedema. All authors have read and agreed to the published version of the manuscript.

Acknowledgments: The authors would like to express their gratitude to twenty interview participants for their valuable contribution to this paper. They would also like to thank four anonymous reviewers for their valuable comments to the previous version of this paper.

Conflicts of Interest: The authors declare no conflict of interest. The funders had no role in the design of the study; in the collection, analyses, or interpretation of data; in the writing of the manuscript, or in the decision to publish the results.

\section{References}

1. Van Engelenburg, B.; Maas, N. Regional Energy Transition (RET): How to improve the connection of praxis and theory? J. Technol. Archit. Environ. Behave. 2018, 1, 62-67.

2. Jordan, A.J.; Huitema, D.; Hildén, M.; Van Asselt, H.; Rayner, T.J.; Schoenefeld, J.J;; Tosun, J.; Förster, J.; Boasson, E.L. Emergence of polycentric climate governance and its future prospects. Nat. Clim. Chang. 2015, 5, 977-982. [CrossRef]

3. Späth, P.; Rohracher, H. The 'eco-cities' Freiburg and Graz: The social dynamics of pioneering urban energy and climate governance. In Cities and Low Carbon Transitions; Bulkeley, H., Broto, V.C., Hodson, M., Marvin, S., Eds.; Routledge: New York, NY, USA; London, UK, 2013; pp. 88-106.

4. Bulkeley, H.; Kern, K. Local Government and the Governing of Climate Change in Germany and the UK. Urban Stud. 2006, 43, 2237-2259. [CrossRef]

5. Boehnke, R.F.; Hoppe, T.; Brezet, H.; Blok, K. Good practices in local climate mitigation action by small and medium-sized cities; exploring meaning, implementation and linkage to actual lowering of carbon emissions in thirteen municipalities in The Netherlands. J. Clean. Prod. 2019, 207, 630-644. [CrossRef]

6. Hoppe, T.; Van Der Vegt, A.; Stegmaier, P. Presenting a Framework to Analyze Local Climate Policy and Action in Small and Medium-Sized Cities. Sustainability 2016, 8, 847. [CrossRef]

7. Betsill, M.M.; Bulkeley, H. Cities and the Multilevel Governance of Global Climate Change. Glob. Gov. 2006, 12, 141-160. [CrossRef]

8. Bulkeley, H. Cities and Climate Change; Informa UK Limited: Colchester, UK, 2013. 
9. Bulkeley, H.; Betsill, M. Rethinking Sustainable Cities: Multilevel Governance and the 'Urban' Politics of Climate Change. Environ. Polit. 2005, 14, 42-63. [CrossRef]

10. Kemp, R.; Rotmans, J.; Loorbach, D. Assessing the Dutch Energy Transition Policy: How Does it Deal with Dilemmas of Managing Transitions? J. Environ. Policy Plan. 2007, 9, 315-331. [CrossRef]

11. Loorbach, D.; Van Der Brugge, R.; Taanman, M. Governance in the energy transition: Practice of transition management in The Netherlands. Int. J. Environ. Technol. Manag. 2008, 9, 294. [CrossRef]

12. Balest, J.; Secco, L.; Pisani, E.; Caimo, A. Sustainable energy governance in South Tyrol (Italy): A probabilistic bipartite network model. J. Clean. Prod. 2019, 221, 854-862. [CrossRef]

13. Jenniches, S.; Worrell, E.; Fumagalli, E. Regional economic and environmental impacts of wind power developments: A case study of a German region. Energy Policy 2019, 132, 499-514. [CrossRef]

14. Mattes, J.; Huber, A.; Koehrsen, J. Energy transitions in small-scale regions - What we can learn from a regional innovation systems perspective. Energy Policy 2015, 78, 255-264. [CrossRef]

15. De Leeuw, L.; Groenleer, M. The Regional Governance of Energy-Neutral Housing: Toward a Framework for Analysis. Sustainability 2018, 10, 3726. [CrossRef]

16. Warbroek, B.; Hoppe, T. Modes of Governing and Policy of Local and Regional Governments Supporting Local Low-Carbon Energy Initiatives; Exploring the Cases of the Dutch Regions of Overijssel and Fryslân. Sustain. 2017, 9, 75. [CrossRef]

17. Coenen, L.; Campbell, S.; Wiseman, J. Regional Innovation Systems and Transformative Dynamics: Transitions in Coal Regions in Australia and Germany. In New Avenues for Regional Innovation Systems-Theoretical Advances, Empirical Cases and Policy Lessons; Springer Science and Business Media LLC: Berlin, Germany, 2018; pp. 199-217.

18. Cooke, P.; Uranga, M.G.; Etxebarria, G. Regional Systems of Innovation: An Evolutionary Perspective. Environ. Plan. A: Econ. Space 1998, 30, 1563-1584. [CrossRef]

19. Boschma, R. Proximity and Innovation: A Critical Assessment. Reg. Stud. 2005, 39, 61-74. [CrossRef]

20. Bemelmans-Videc, M.L.; Rist, R.C.; Vedung, E.O. (Eds.) Carrots, Sticks, and Sermons: Policy Instruments and Their Evaluation; Transaction Publishers: Piscataway, NJ, USA, 2011; Volume 1.

21. Coenen, L.; Asheim, B.; Bugge, M.M.; Herstad, S.J. Advancing regional innovation systems: What does evolutionary economic geography bring to the policy table? Environ. Plan. C: Polit. Space 2017, 35, 600-620. [CrossRef]

22. Wäckerlin, N.; Hoppe, T.; Warnier, M.; De Jong, W.M. Comparing city image and brand identity in polycentric regions using network analysis. Place Brand. Public Dipl. 2019, 1-17. [CrossRef]

23. Benner, J.; Leguijt, C.; Ganzevles, J.; Van Est, R. Energietransitie begint in de regio: Rotterdam, Texel en Energy Valley onder de loep; Rathenau Instituut: The Hague, The Netherlands, 2009; p. 82.

24. Kuhlmann, S. Future governance of innovation policy in Europe-Three scenarios. Res. Policy 2001, 30, 953-976. [CrossRef]

25. Smith, A. Translating Sustainabilities between Green Niches and Socio-Technical Regimes. Technol. Anal. Strat. Manag. 2007, 19, 427-450. [CrossRef]

26. Lutz, L.M.; Fischer, L.-B.; Newig, J.; Lang, D.J. Driving factors for the regional implementation of renewable energy - A multiple case study on the German energy transition. Energy Policy 2017, 105, 136-147. [CrossRef]

27. Hoppe, T.; Graf, A.; Warbroek, B.; Lammers, I.; Lepping, I. Local Governments Supporting Local Energy Initiatives: Lessons from the Best Practices of Saerbeck (Germany) and Lochem (The Netherlands). Sustainability 2015, 7, 1900-1931. [CrossRef]

28. Grin, J.; Rotmans, J.; Schot, J. Transitions to Sustainable Development: New Directions in the Study of Long Term Transformative Change; Routledge: New York, NY, USA, 2010.

29. Kemp, R. Technology and the Transition to Environmental Sustainability-The Problem of Technological Regime Shifts. Futures 1994, 26, 1023-1046. [CrossRef]

30. Kemp, R.; Schot, J.; Hoogma, R. Regime shifts to sustainability through processes of niche formation: The approach of strategic niche management. Technol. Anal. Strat. Manag. 1998, 10, 175-198. [CrossRef]

31. Geels, F. Processes and patterns in transitions and system innovations: Refining the co-evolutionary multi-level perspective. Technol. Forecast. Soc. Chang. 2005, 72, 681-696. [CrossRef]

32. Geels, F.W. Technological transitions as evolutionary reconfiguration processes: A multi-level perspective and a case-study. Res. Policy 2002, 31, 1257-1274. [CrossRef] 
33. Loorbach, D. Transition Management: New Mode of Governance for Sustainable Development; International Books: Utrecht, The Netherlands, 2007.

34. Loorbach, D.; Rotmans, J. The practice of transition management: Examples and lessons from four distinct cases. Futures 2010, 42, 237-246. [CrossRef]

35. Frantzeskaki, N.; Hölscher, K.; Holman, I.P.; Pedde, S.; Jaeger, J.; Kok, K.; Harrison, P.A. Transition pathways to sustainability in greater than $2^{\circ} \mathrm{C}$ climate futures of Europe. Reg. Environ. Chang. 2019, 19, 777-789. [CrossRef]

36. Roesler, T.; Hassler, M. Creating niches-The role of policy for the implementation of bioenergy village cooperatives in Germany. Energy Policy 2019, 124, 95-101. [CrossRef]

37. Moss, T.; Becker, S.; Naumann, M. Whose energy transition is it, anyway? Organisation and ownership of the Energiewende in villages, cities and regions. Local Environ. 2015, 20,1547-1563. [CrossRef]

38. Hooghe, L.; Marks, G.; Schakel, A.H.; Osterkatz, S.C.; Niedzwiecki, S.; Shair-Rosenfield, S. Measuring Regional Authority: A Postfunctionalist Theory of Governance; Oxford University Press: Oxford, UK, 2016; Volume 1.

39. Andersen, O.J.; Pierre, J. Exploring the Strategic Region: Rationality, Context, and Institutional Collective Action. Urban Aff. Rev. 2010, 46, 218-240. [CrossRef]

40. Jacobsen, D.I. Regional Governance Networks: Filling In or Hollowing Out? Scand. Polit. Stud. 2015, 38, 115-136. [CrossRef]

41. Boogers, M.; Klok, P.J.; Denters, S.A.; Sanders, M.; Linnenbank, M. Effecten van regionaal bestuur voor gemeenten: Bestuursstructuur, samenwerkingsrelaties, democratische kwaliteit en bestuurlijke effectiviteit; Universiteit Twente: Enschede, The Netherlands, 2016.

42. Klok, P.-J.; Denters, B.; Boogers, M.; Sanders, M. Intermunicipal Cooperation in The Netherlands: The Costs and the Effectiveness of Polycentric Regional Governance. Public Adm. Rev. 2018, 78, 527-536. [CrossRef]

43. Bevir, M. Governance: A Very Short Introduction; OUP: Oxford, UK, 2012.

44. Turrini, A.; Cristofoli, D.; Frosini, F.; Nasi, G. Networking literature about determinants of network effectiveness. Public Admin. 2010, 88, 528-550. [CrossRef]

45. Klijn, E.-H. Governance and governance networks in Europe: An assessment of ten years of research on the theme. J. Public Manag. Rev. 2008, 10, 505-525. [CrossRef]

46. Rittel, H.W.; Webber, M.M. Dilemmas in a general theory of planning. Policy Sci. 1973, 4, 155-169. [CrossRef]

47. Van Bueren, E.; Klijn, E.; Koppenjan, J. Dealing with wicked problems in networks: Analyzing an environmental debate from a network perspective. J. Public Admin. Res. Theory 2003, 13, 193-212. [CrossRef]

48. Kickert, W.J.M.; Klijn, E.-H.; Koppenjan, J.F.M. (Eds.) Managing Complex Networks: Strategies for the Public Sector; SAGE: London, UK; Thousand Oaks, CA, USA; New Delhi, India, 1997; p. 206.

49. Klijn, E.-H.; Steijn, B.; Edelenbos, J. The Impact of Network Management on Outcomes in Governance Networks. Public Adm. 2010, 88, 1063-1082. [CrossRef]

50. Klijn, E.-H. Regels en sturing in netwerken: De invloed van netwerkregels op de herstructurering van naoorlogse wijken; Erasmus Universiteit: Rotterdam, The Netherlands, 1996.

51. Milward, H.B.; Provan, K.G.; Fish, A.; Isett, K.R.; Huang, K. Governance and Collaboration: An Evolutionary Study of Two Mental Health Networks. J. Public Adm. Res. Theory 2009, 20, i125-i141. [CrossRef]

52. De Bruijn, H.; Ten Heuvelhof, E. Process Management: Why Project Management Fails in Complex Decision Making Processes; Springer Science \& Business Media: Berlin, Germany, 2010.

53. Teisman, G.; Gerrits, L.J.C. The emergence of complexity in the art and science of governance. Complex. Gov. Netw. 2014, 1, 17-28.

54. O'Toole, L.J.; Meier, K.J. Public Management in Intergovernmental Networks: Matching Structural Networks and Managerial Networking. J. Public Adm. Res. Theory 2004, 14, 469-494. [CrossRef]

55. Van Bueren, E. Greening Governance: An Evolutionary Approach to Policy Making for a Sustainable Built Environment; IOS Press: Amsterdam, The Netherlands, 2009; Volume 30.

56. Sabatier, P.A. An advocacy coalition framework of policy change and the role of policy-oriented learning therein. Policy Sci. 1988, 21, 129-168. [CrossRef]

57. Granovetter, M. The Strength of Weak Ties: A Network Theory Revisited. Sociol. Theory 1983, 1, 201. [CrossRef]

58. Klijn, E.-H.; Edelenbos, J.; Steijn, B. Trust in governance networks: Its impacts on outcomes. J. Admin. Soc. 2010, 42, 193-221. [CrossRef] 
59. Bressers, H.; Bressers, N.; Kuks, S.; Larrue, C. The Governance Assessment Tool and Its Use. In Governance for Drought Resilience; Springer: Berlin, Germany, 2016; pp. 45-65.

60. Ostrom, E. Understanding Institutional Diversity; Princeton University Press: Princeton, NJ, USA, 2009; p. 376.

61. Hoppe, T.; Kooijman-van Dijk, A.; Arentsen, M. Governance of bio-energy: The case of Overijssel. In Proceedings of the Resilient Societies Conference, IGS, University of Twente, Enschede, The Netherlands, 19-21 October 2011.

62. Sanders, M.; Heldeweg, M.A.; Brunnekreef, A.V. Governance of Heat Grids: Towards a Governance Typology for Smart Heat Infrastructures. In Proceedings of the 2nd ESEIA International Conference on Smart and Green Transitions in Cities \& Regions 2016, Graz, Austria, 4-6 April 2016.

63. Fuchs, G.; Hinderer, N. Situative governance and energy transitions in a spatial context: Case studies from Germany. Energy Sustain. Soc. 2014, 4, 16. [CrossRef]

64. Fligstein, N.; McAdam, D. Toward a General Theory of Strategic Action Fields*. Sociol. Theory 2011, 29, 1-26. [CrossRef]

65. Hoppe, T.; Van Bueren, E. Guest editorial: Governing the challenges of climate change and energy transition in cities. Energy Sustain. Soc. 2015, 5, 1-9. [CrossRef]

66. Leck, H.; Simon, D. Fostering multiscalar collaboration and co-operation for effective governance of climate change adaptation. Urban Stud. 2013, 50, 1221-1238. [CrossRef]

67. Bedsworth, L.W.; Hanak, E. Climate policy at the local level: Insights from California. Glob. Environ. Chang. 2013, 23, 664-677. [CrossRef]

68. Kern, K.; Bulkeley, H. Cities, Europeanization and Multi-level Governance: Governing Climate Change through Transnational Municipal Networks. JCMS: J. Common Mark. Stud. 2009, 47, 309-332. [CrossRef]

69. Hoppe, T.; Coenen, F. Creating an analytical framework for local sustainability performance: A Dutch Case Study. Local Environ. 2011, 16, 229-250. [CrossRef]

70. Reckien, D.; Salvia, M.; Heidrich, O.; Church, J.M.; Pietrapertosa, F.; De Gregorio-Hurtado, S.; D’Alonzo, V.; Foley, A.; Simões, S.G.; Lorencová, E.K.; et al. How are cities planning to respond to climate change? Assessment of local climate plans from 885 cities in the EU-28. J. Clean. Prod. 2018, 191, 207-219. [CrossRef]

71. Sanders, M.P.; A Heldeweg, M.; Straatman, E.G.; Wempe, J.F. Energy policy by beauty contests: The legitimacy of interactive sustainability policies at regional levels of the regulatory state. Energy Sustain. Soc. 2014, 4, 4 . [CrossRef]

72. Warbroek, B.; Hoppe, T.; Coenen, F.; Bressers, H. The Role of Intermediaries in Supporting Local Low-Carbon Energy Initiatives. Sustainabilty 2018, 10, 2450. [CrossRef]

73. Schuurs, R.; Schwencke, A.M. Lessen voor een Regionale Energietransitie: Slim schakelen; IPO, VNG, UVW, Rijksoverheid: The Hague, The Netherlands, 2017; pp. 1-50.

74. Boogers, M.; Klok, P.J. Praktijk van regionaal bestuur in Noord-Brabant; Universiteit Twente: Enschede, The Netherlands, 2017; pp. 1-47.

75. Regiegroep Regionale Energiestrategie West-Brabant. Energiestrategie voor de regio West-Brabant: Ons2050; RWB: Etten-Leur, The Netherlands, 2017; pp. 1-63.

76. Elzenga, H.; Schwencke, A.; Hoorn, A.V. Het handelingsperspectief van gemeenten in de energietransitie naar een duurzame warmte —en elektriciteitsvoorziening; PBL: The Hague, The Netherlands, 2017; p. 83.

77. Schwencke, A.M. Lokale Energie Monitor 2019; HIER opgewekt/RVO: Utrecht, The Netherlands, 2019; pp. 1-195.

78. Miedema, M. Naar een regionale energietransitie; Analyse van de samenwerking aan de verduurzaming van de energievoorziening van de woningvoorraad in West-Brabant; EUR/TU Delft: Rotterdam/Delft, The Netherlands, 2018; pp. 1-125.

79. Niemann, L.; Hoppe, T.; Coenen, F. On the Benefits of Using Process Indicators in Local Sustainability Monitoring: Lessons from a Dutch Municipal Ranking (1999-2014). Environ. Policy Gov. 2017, 27, $28-44$. [CrossRef]

80. Hoppe, T.; de Vries, G. Social Innovation and the Energy Transition. Sustainability 2019, 11, 141. [CrossRef]

(C) 2020 by the authors. Licensee MDPI, Basel, Switzerland. This article is an open access article distributed under the terms and conditions of the Creative Commons Attribution (CC BY) license (http://creativecommons.org/licenses/by/4.0/). 